\title{
RELATIONSHIP BETWEEN PEAK GROUND ACCELERATION AND MODIFIED MERCALLI INTENSITY IN COSTA RICA
}

\author{
Lepolt Linkimer
}

\author{
Laboratorio de Ingeniería Sísmica, Instituto de Investigaciones en Ingeniería, \\ Universidad de Costa Rica, Apdo. 36-2060, San Pedro Montes de Oca, Costa Rica. \\ Present address: Department of Geosciences, The University of Arizona, \\ Gould-Simpson 208, Tucson AZ, 85721, USA. \\ linkimer@email.arizona.edu
}

(Recibido 29/07/07; aceptado 03/05/08)

\begin{abstract}
The first relationship between Modified Mercalli Intensity (MMI) scale and the horizontal component of Peak Ground Acceleration (PGA) was developed for the Costa Rican region using regression analysis of 108 earthquakes $(2.8<\mathrm{Mw}<7.7)$ that occurred between 1983 and 2004. For each PGA instrumentally recorded, a single MMI value was assigned based on the geographic proximity to the PGA observation. A total of 330 values of both the largest PGA of the two horizontal components $\left(\mathrm{PGA}_{\max }\right)$ and the average of the two horizontal components $\left(\mathrm{PGA}_{\text {ave }}\right)$ were associated to $\mathrm{MMI}$ values. The correlations obtained are: $\mathrm{MMI}=2.30 \log \left(\mathrm{PGA}_{\max }\right)+0.92$ and $\mathrm{MMI}=2.33 \log \left(\mathrm{PGA}_{\text {ave }}\right)+0.76$ for $\mathrm{MMI} \mathrm{II}-\mathrm{V}$ and $\mathrm{MMI}=3.82 \log \left(\mathrm{PGA}_{\max }\right)-1.78$ and $\mathrm{MMI}=4.60 \log \left(\mathrm{PGA}_{\text {ave }}\right)-3.38$ for MMI V-VII. Predicted PGA intervals for each intensity unit were proposed based on these equations. There is a fairly remarkable agreement between the $\mathrm{PGA}_{\max }$ vs. MMI found in this study and the correlation calculated by Wald et al. (1999a) for California.

Keywords: Modified Mercalli Intensity, Peak Ground Acceleration, Regression Analysis, Macroseismic Information, Costa Rica.

RESUMEN: La primera correlación entre la intensidad Mercalli Modificada (MMI) y la componente horizontal de la aceleración pico del suelo (PGA) fue desarrollada para Costa Rica a partir de la regresión de 108 sismos $(2,8<$ Mw < 7,7) que ocurrieron entre 1983 y 2004. Para cada PGA registrado instrumentalmente, un único valor de MMI fue asignado basado en la proximidad geográfica del PGA observado. Un total de 330 valores de la aceleración más alta entre las dos componentes horizontales $\left(\mathrm{PGA}_{\max }\right.$ ) y del promedio de las dos componentes horizontales $\left(\mathrm{PGA}_{\text {ave }}\right.$ ) fue asociado con MMI. Las correlaciones obtenidas son: $\mathrm{MMI}=2,30 \log \left(\mathrm{PGA}_{\max }\right)+0,92$ y $\mathrm{MMI}=2,33 \log \left(\mathrm{PGA}_{\text {ave }}\right)+0,76$ para $\mathrm{MMI}$ II-V y $\mathrm{MMI}=3,82 \log \left(\mathrm{PGA}_{\max }\right)-1,78$ y $\mathrm{MMI}=4,60 \log \left(\mathrm{PGA}_{\text {ave }}\right)-3,38$ para MMI V-VII. Con base en estas ecuaciones fueron propuestos intervalos de PGA para cada unidad de intensidad. La correlación entre PGA max $_{\text {y }}$ MI encontrada en este estudio es notablemente similar a la correlación calculada por Wald et al. (1999a) para California.

Palabras clave: Intensidad Mercalli Modificada, aceleración pico del suelo, análisis de regresión, Información macrosísmica, Costa Rica.
\end{abstract}

LINKIMER, L., 2008: Relationship Between Peak Ground Acceleration and Modified Mercalli Intensity in Costa Rica. - Rev. Geol. Amér. Central, 38: 81-94. 


\section{INTRODUCTION}

Seismic intensity and ground motion acceleration are two parameters that describe the degree of ground shaking for earthquakes. Seismic intensity is based on human response to ground shaking, damage observations, and earthquake effects and is commonly measured using the Modified Mercalli Intensity (MMI) scale, which is expressed as Roman numerals between I and XII (Wood \& Newman, 1931; Richter, 1958). A more objective representation of the degree of shaking is given by the ground motion acceleration that is measured using accelerographs and is expressed in $\mathrm{cm} / \mathrm{s}^{2}$, gals, or as a percentage of the gravity acceleration. The Peak Ground Acceleration (PGA) is used here as the maximum absolute value of acceleration found for particular strong motion record.

Costa Rica is located in a seismically active region. Since 1900, there have been 11 large (Ms > 7.0) damaging earthquakes (Ambraseys \& Adams, 2001). This high seismicity is related to the interaction of three tectonic blocks: the Cocos, Caribbean, and Nazca plates (Fig. 1). The majority of the earthquakes are associated with the subduction of the Cocos plate underneath the Caribbean plate, the North Panama Deformed Belt (NPDB), the Panama Fracture Zone (PFZ), and also with crustal faults located in the interior of the country.

The main goal of this study is to develop a relationship that can be used to estimate seismic intensity rapidly given instrumental ground motion recordings for the Costa Rican region. The questions to be answered are: How well correlated is MMI to PGA in Costa Rica? How similar is the MMI vs. PGA relationship for Costa Rica to correlations found in other regions? Previous studies have suggested that empirical relationships between ground motion parameters and MMI are region-specific and therefore they should be carefully calculated for a particular region (Murphy \& O'Brien; 1977; Kaka \& Atkinson, 2004). One of the first attempts to correlate earthquake inten- sity and instrumental strong motion parameters was presented by Cancani (1904), who proposed a range of PGA for each degree of intensity. Since then, numerous correlations have been published for particular regions, as summarized in Table 1. Other contributions to this subject have been presented by Newman (1954), Gupta (1980), McCann et al. (1980), Chiaruttini \& Siro (1981), Schenk et al. (1990), Atkinson \& Boore (1995), Atkinson \& Sonley (2000), Atkinson (2001), Boatwright et al. (2001), and Wu et al. (2003).

One evident application of the MMI vs. PGA correlation is to obtain MMI information from available PGA data. This exercise could be the first step in Costa Rica for the development of shaking intensity maps like those created in California a few minutes after the occurrence of felt earthquakes. These maps are created using empirical relationships between ground motion parameters and MMI and give a rapid representation of potentially damaged regions that can be used for emergency response and public information through the media (Wald et al., 1999b). Currently, intensity maps are not made available by Costa Rican seismic networks as part of their immediate response after the occurrence of felt earthquakes.

Another possible application would be to obtain PGA information from MMI data. In this case, the MMI vs. PGA correlation could extend the PGA knowledge to earthquakes that occurred before 1983, when the majority of strong motion instruments were deployed in the country. This may be significant, since there is available MMI data determined from historical reports for earthquakes that occurred since 1678 (González, 1910; Peraldo \& Montero, 1994). Given that instrument coverage is still limited to populated areas, it would also be possible to calculate PGA in rural areas where MMI is observed, but there is no strong motion data. It is important to emphasize that calculating PGA from MMI data should be done with cautious because the correlations obtained in this study were solved for MMI given PGA values and the correlation in the opposite direction does not necessarily hold the same. 


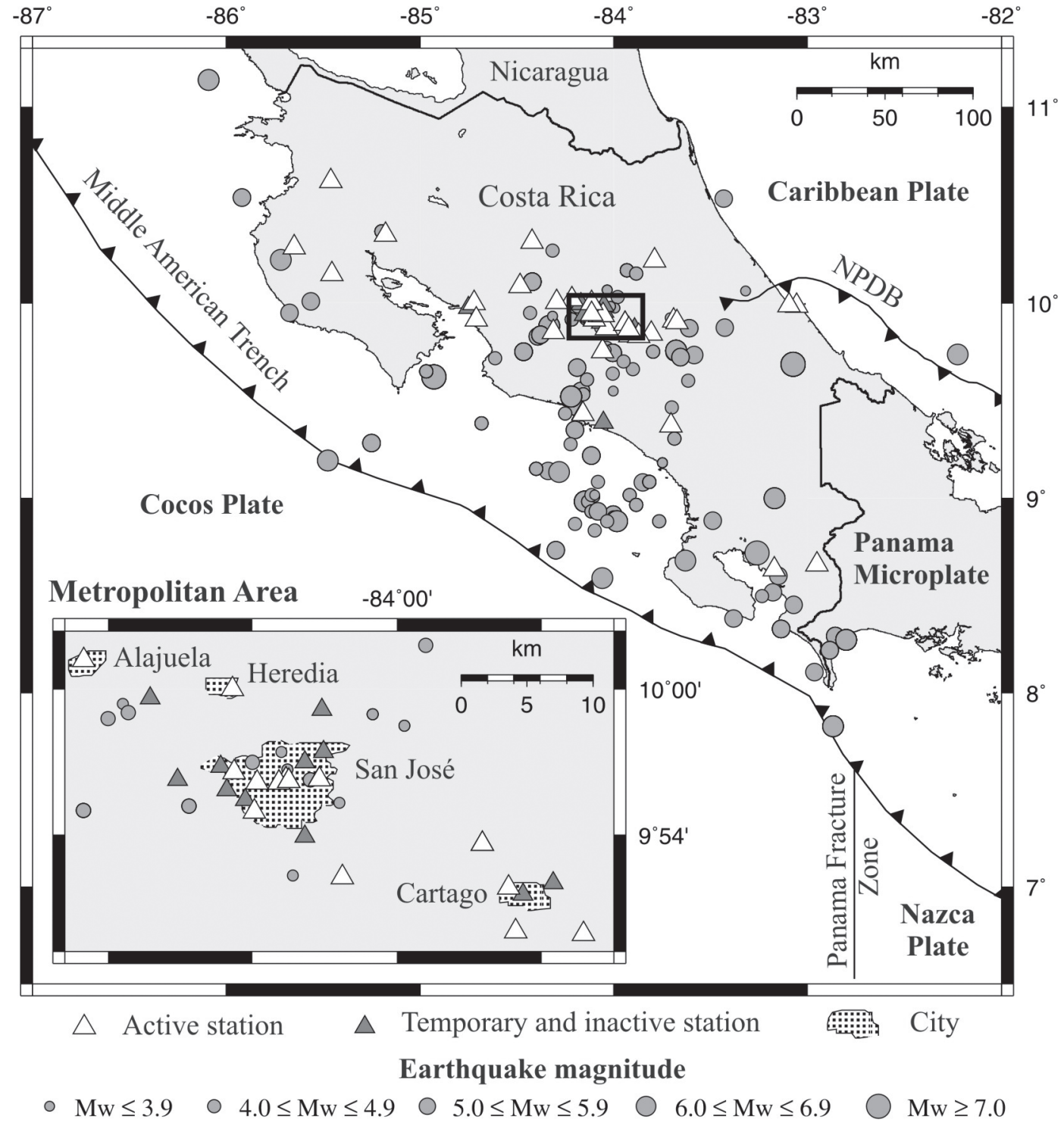

Fig. 1: Major tectonic features of Costa Rica and western Panama and location of LIS ground motion stations and earthquakes used in this study. NPDB: North Panama Deformed Belt.

\section{DATA SOURCES AND METHODOLOGY}

Strong motion data come from the Laboratory of Earthquake Engineering (LIS by its Spanish acronym) of the University of Costa Rica (UCR).
LIS has a permanent network of 35 active strong motion stations mainly distributed in the densely populated Metropolitan Area of Costa Rica. Data recorded from temporary and inactive LIS stations were also used in this study (Fig. 1). 
Table 1

Correlations between PGA $\left(\mathrm{cm} / \mathrm{s}^{2}\right)$ and MMI

\begin{tabular}{|c|c|c|}
\hline Reference & Correlation & Region \\
\hline \multirow[t]{2}{*}{ This study (all data) } & $\mathrm{MMI}=2.30 \log \left(\mathrm{PGA}_{\max }\right)+0.92($ from II $>$ MMI $>$ V) & Costa Rica \\
\hline & $\mathrm{MMI}=3.82 \log \left(\mathrm{PGA}_{\max }\right)-1.78($ from $\mathrm{V}>\mathrm{MMI}>\mathrm{VII})$ & \\
\hline \multirow[t]{2}{*}{ This study (all data) } & $\mathrm{MMI}=2.33 \log \left(\mathrm{PGA}_{\mathrm{ave}}\right)+0.76($ from $\mathrm{II}>\mathrm{MMI}>\mathrm{V})$ & Costa Rica \\
\hline & $\mathrm{MMI}=4.60 \log \left(\mathrm{PGA}_{\mathrm{ave}}\right)-3.38($ from $\mathrm{V}>\mathrm{MMI}>\mathrm{VII})$ & \\
\hline $\begin{array}{l}\text { Gutenberg \& Richter }(1942 ; 1956) \\
\text { and Richter (1958) }\end{array}$ & $\mathrm{MMI}=3.00 \log \left(\mathrm{PGA}_{\mathrm{ave}}\right)+1.50$ & Western USA \\
\hline Hershberger (1956) & $\mathrm{MMI}=2.33 \log \left(\mathrm{PGA}_{\mathrm{ave}}\right)+2.1$ & Western USA \\
\hline Trifunac \& Brady (1975) & $\mathrm{MMI}=3.33 \log \left(\mathrm{PGA}_{\mathrm{ave}}\right)-0.47($ from $\mathrm{IV}<\mathrm{MMI}<\mathrm{X})$ & Western USA \\
\hline Murphy \& O’Brien (1977) & $\mathrm{MMI}=2.86 \log \left(\mathrm{PGA}_{\mathrm{ave}}\right)+1.24($ from $\mathrm{IV}<\mathrm{MMI}<\mathrm{X})$ & $\begin{array}{l}\text { Western USA, Japan, and } \\
\text { Southern Europe }\end{array}$ \\
\hline Murphy \& O’Brien (1977) & $\mathrm{MMI}=4.00 \log \left(\mathrm{PGA}_{\max }\right)-1.00($ from $\mathrm{IV}<\mathrm{MMI}<\mathrm{VIII})$ & $\begin{array}{l}\text { Western USA, Japan, and } \\
\text { Southern Europe }\end{array}$ \\
\hline Sauter \& Shah (1978) & $\mathrm{MMI}=3.62 \log \left(\mathrm{PGA}_{\mathrm{ave}}\right)-0.90$ & Unspecified \\
\hline \multirow[t]{2}{*}{ Wald et al. (1999a) } & $\mathrm{MMI}=2.20 \log \left(\mathrm{PGA}_{\max }\right)+1.00($ from $\mathrm{MMI}<\mathrm{V})$ & California \\
\hline & $\mathrm{MMI}=3.66 \log \left(\mathrm{PGA}_{\max }\right)-1.66($ from $\mathrm{V}<\mathrm{MMI}<\mathrm{VIII})$ & \\
\hline
\end{tabular}

Note: PGAave is the PGA average of the two horizontal components and PGAmax is the largest PGA of the two horizontal components.

Macroseismic information was acquired from the National Seismological Network of Costa Rica (RSN), which comprises the earthquake unit of the Central American School of Geology of UCR and the Costa Rican Institute of Electricity (ICE). MMI and isoseismal maps come from unpublished bulletins made by RSN, LIS, descriptions from local newspapers, and interviews made at the location of strong motion stations during the week of earthquake occurrence.

A compilation of three-component PGA and MMI of 108 earthquakes $(2.8<\mathrm{Mw}<7.7)$ that occurred between 1983 and 2004 was performed. PGA values were calculated using a program written in Fortran that compares acceleration values along the seismic record and gives the maximum value for each component. Both, the largest of the two horizontal components $\left(\mathrm{PGA}_{\max }\right.$ ) and the average of the two horizontal components $\left(\mathrm{PGA}_{\text {ave }}\right)$ were calculated for the sake of comparison with previous MMI vs. PGA correlations.

For each instrumentally recorded event, a single MMI value was assigned based on the geographic proximity $(<3 \mathrm{~km})$ to one or more MMI observations. Figure 2 shows an example of data collected for the December 25, 2003 Armuelles $(6.6 \mathrm{Mw})$ earthquake. Stations located in tall buildings ( $\geq 3$ stories) were not used in this analysis, since the response of tall structures may significantly affect the value of acceleration recorded. A total of 330 values of PGA in the horizontal component were associated to a single MMI value. Geometric and arithmetic means were calculated for both the $\mathrm{PGA}_{\max }$ and $\mathrm{PGA}_{\text {ave }}$ for each intensity unit. Linear regressions were performed on the PGAmax geometric mean and PGAave arithmetic mean for a given intensity unit using the method of least squares.

\section{Description of the data}

The data is composed of 330 PGA values associated with MMI values from 108 earthquakes. Figures 3 and 4 show the distribution of the data in terms of different parameters, and Table 2 the mean and standard deviation for each intensity unit. The majority of the PGA-MMI observations 


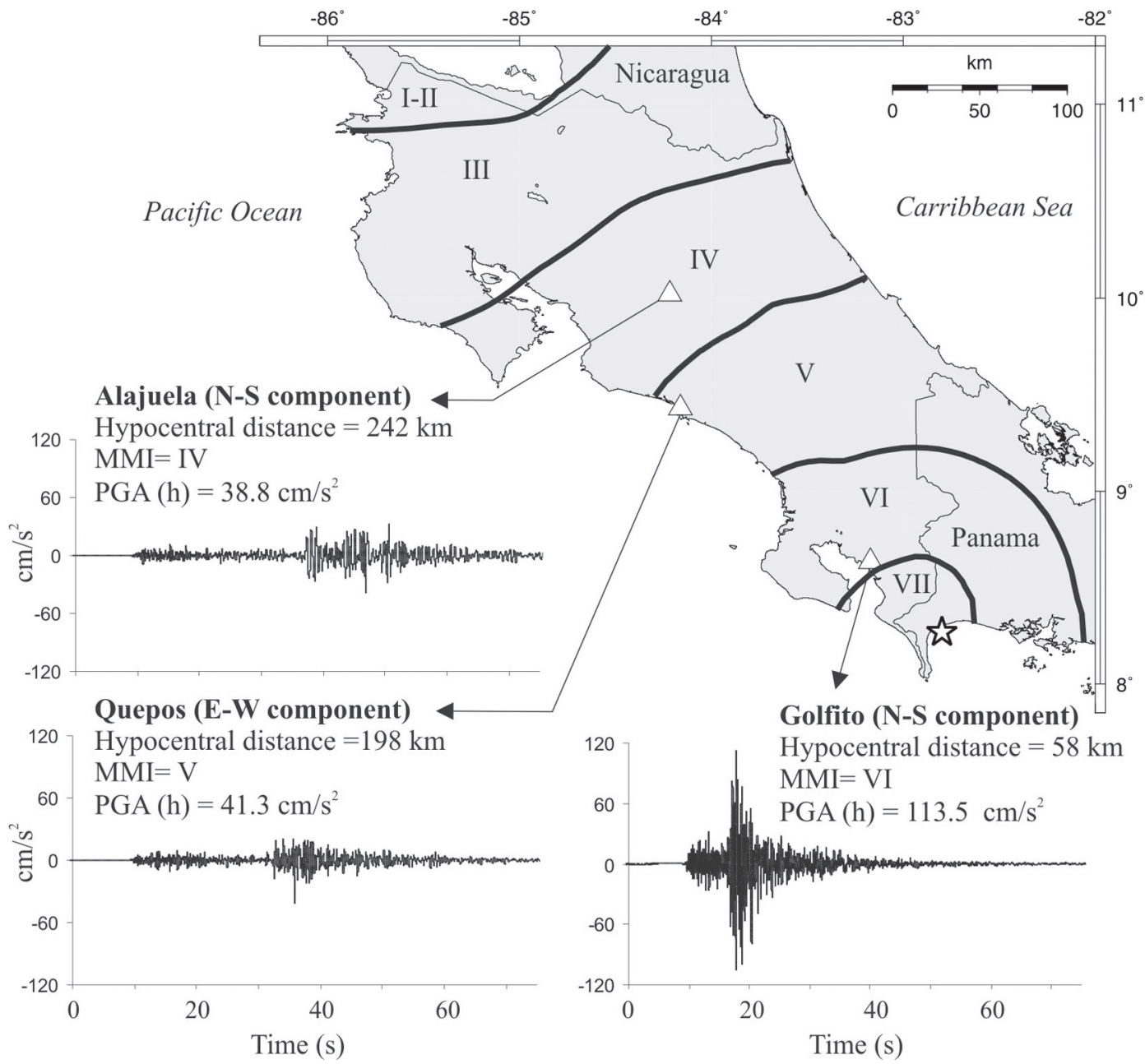

Fig. 2: PGA and observed MMI at three LIS strong motion stations due to the December 25, 2003 Armuelles (6.6 Mw) earthquake. The accelerograms shown correspond to the horizontal component that recorded the largest of the two horizontal PGA. The white star denotes the epicentral location. The contours of equal intensity are taken from Linkimer (in press).

Table 2

Mean and standard deviation $(\sigma)$ of the PGA $(\mathrm{cm} / \mathrm{s} 2)$ data set for each MMI

\begin{tabular}{|c|c|c|c|c|c|}
\hline Intensity (MM) & Number of points & $\begin{array}{c}\text { Geometric mean } \\
\left(\text { PGA }_{\max }\right)\end{array}$ & $\left(\mathrm{PGA}_{\max }\right)$ & $\begin{array}{c}\text { Arithmetic mean } \\
\left(\mathrm{PGA}_{\text {ave }}\right)\end{array}$ & $\left(\mathrm{PGA}_{\mathrm{ave}}\right)$ \\
\hline II & 76 & 2.7 & 2.21 & 3.04 & 2.08 \\
\hline III & 69 & 9.0 & 11.88 & 10.87 & 10.06 \\
\hline IV & 78 & 23.7 & 19.36 & 26.08 & 16.35 \\
\hline $\mathrm{V}$ & 73 & 53.5 & 45.31 & 58.61 & 38.21 \\
\hline VI & 29 & 96.3 & 57.48 & 97.54 & 51.08 \\
\hline VII & 5 & 203.1 & 109.30 & 197.79 & 93.22 \\
\hline
\end{tabular}



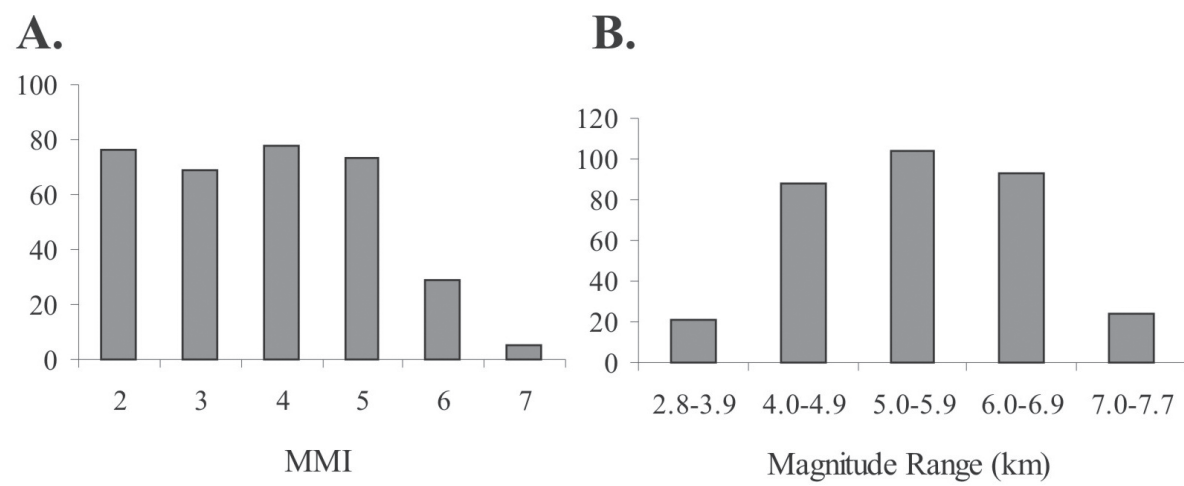

\section{C.}

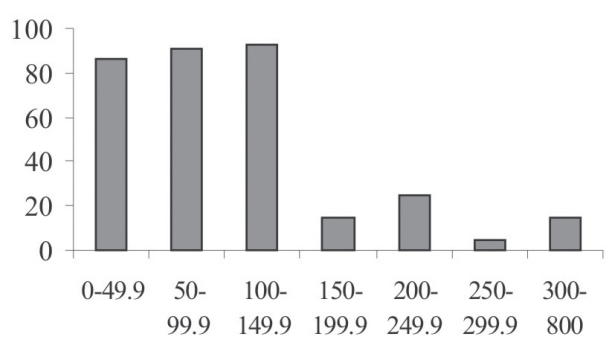

Hypocentral Distance Range (km)

$$
\text { E. }
$$

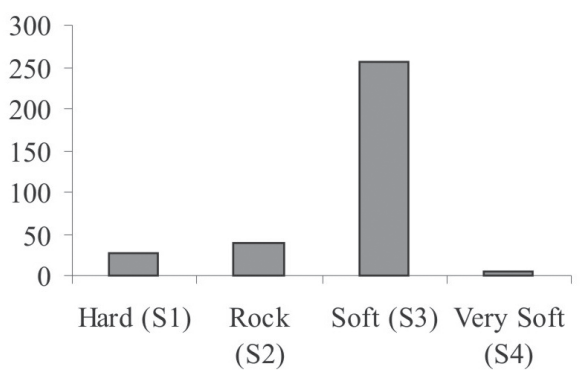

Soil Type at Station
D.

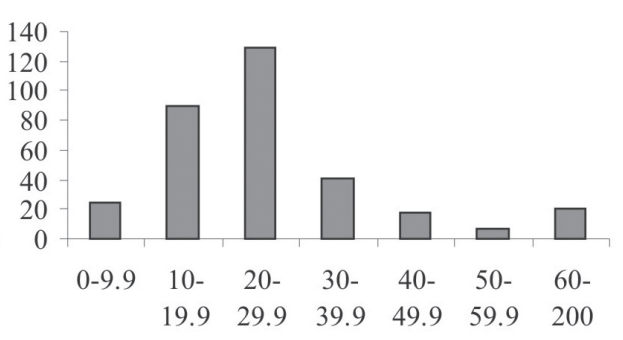

Depth Range (km)

F.

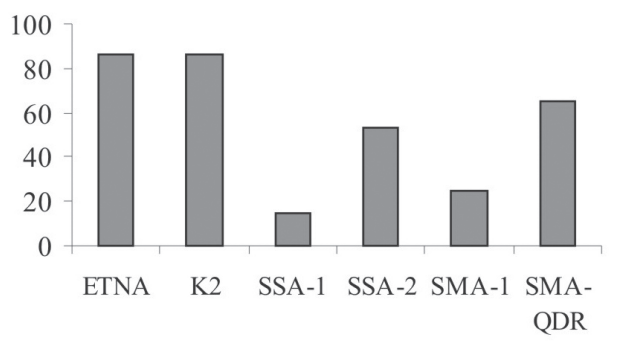

Type of Accelerograph

Fig. 3: Histograms showing the distribution of the data set with respect to: A) MMI. B) Earthquake magnitude. C) Hypocentral distance. D) Focal depth. E) Soil type at the strong motion station. F) Type of accelerograph.

are distributed in the MMI range of II-V (89.7 $\%$, Fig. 3A). Most of the observations of the data sample come from earthquakes with magnitudes of 4.0-6.9 (86.4\%, Fig. 3B), recorded at hypocentral distances of $<150 \mathrm{~km}(81.2 \%$, Fig. 3C) and with focal depths of $<40 \mathrm{~km}$ (86.4\%, Fig. 3D).
The soil type at the strong motion stations was classified according to the latest version of the seismic code of Costa Rica (Colegio Federado de Ingenieros y Arquitectos, 2003) in four types: Rock (S1), Hard (S2), Soft (S3), and Very Soft (S4). Most of the stations (77.9\%, Fig. 3E) are 


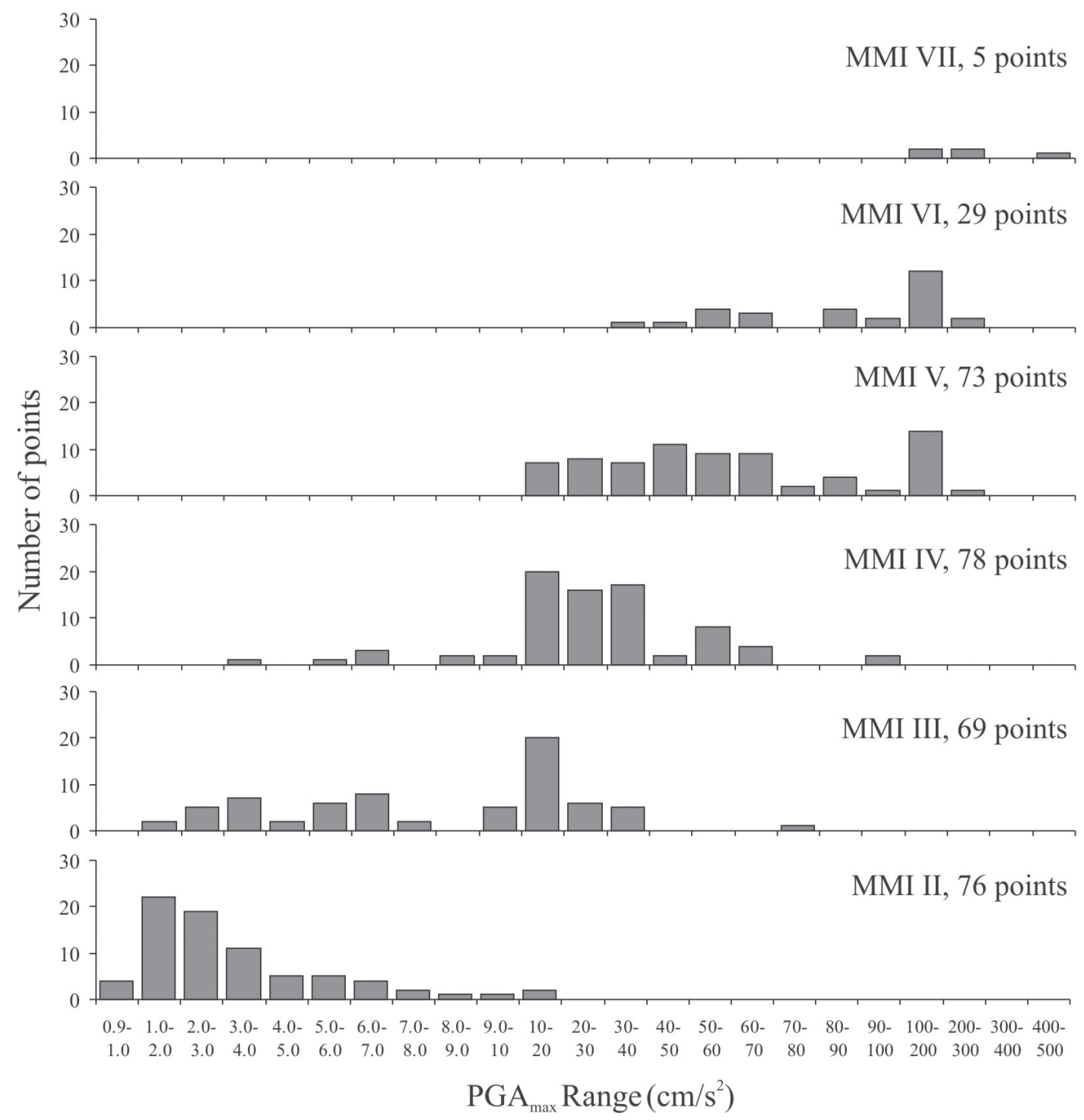

Fig. 4: Histograms showing the distribution of PGAmax values for a given MMI.

located on soft type soils, represented by alluvial deposits and highly weathered volcanic deposits. Ground acceleration was mostly $(92.4 \%$, Fig 3F) recorded by digital accelerographs of the models Etna, K2, SSA-1, SSA-2, and SMA-QDR from Kinemetrics Inc.

\section{THE RELATIONSHIP BETWEEN PGA AND MMI FOR COSTA RICA}

In Costa Rica, MMI and PGA can be related by the equations (Fig. 5A, B):

$\mathrm{MMI}=2.69 \log \left(\mathrm{PGA}_{\max }\right)+0.56$ 
A.

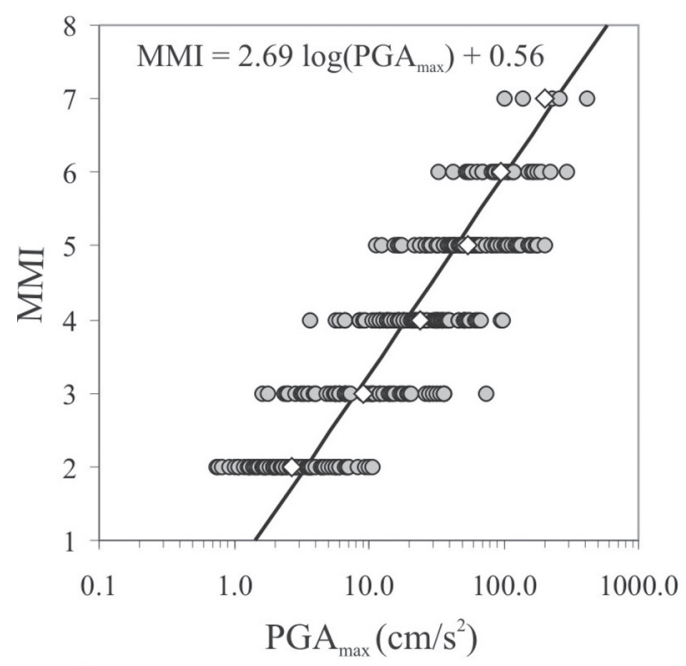

C.

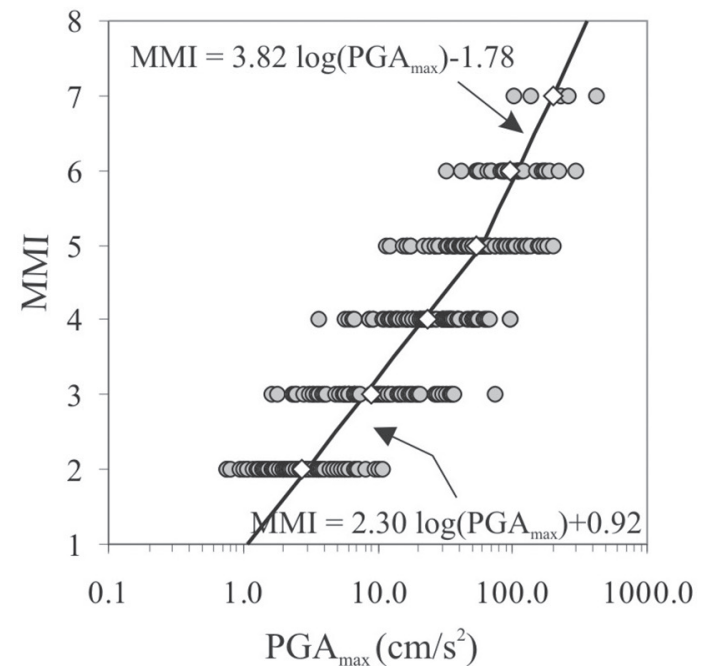

B.

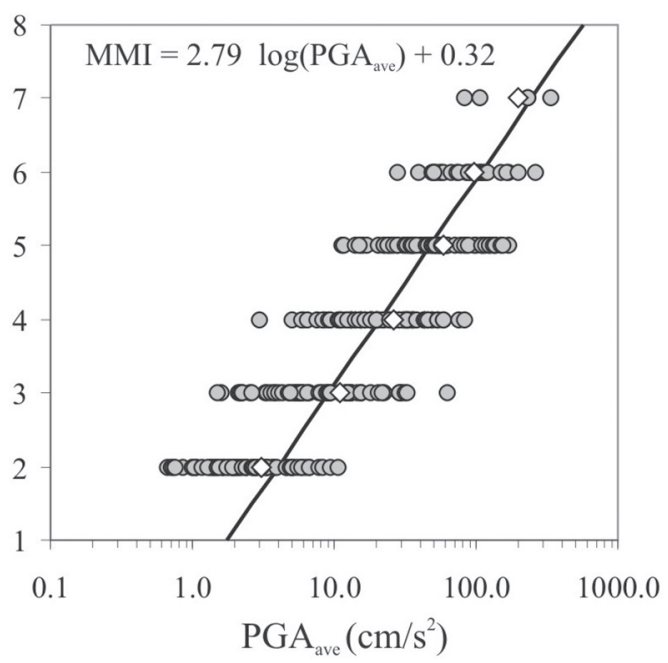

D.

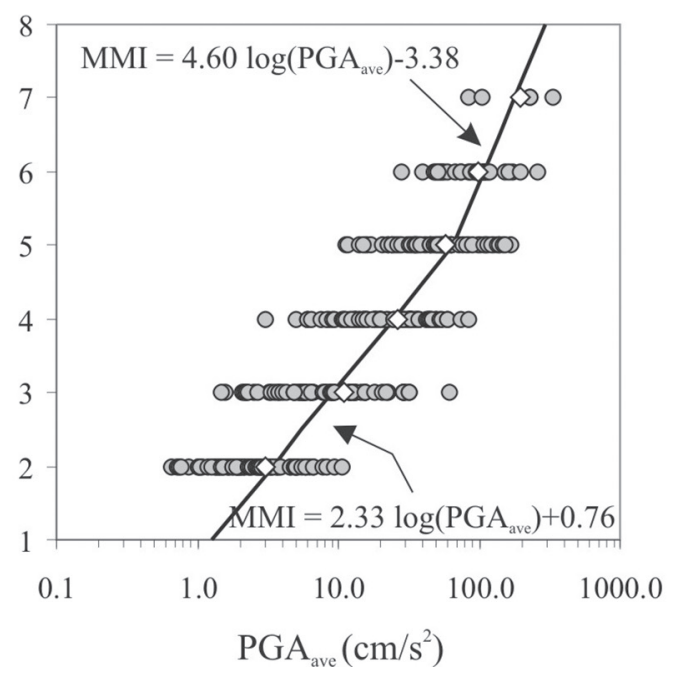

Fig. 5: PGA vs MMI correlations for the Costa Rican region. Circles denote data and black solid lines the regression for the mean (diamonds) for a given intensity unit. A) MMI vs. PGAmax and regression line for the geometric mean. B) MMI vs. PGAave and regression line for the arithmetic mean. C) MMI vs. PGA max and regression line for the geometric mean of higher $(\mathrm{V}>\mathrm{MMI}>$ VI) and lower (II $>$ MMI $>$ V) intensities. D) MMI vs. PGAave and regression line for the arithmetic mean of higher (V > MMI $>$ $\mathrm{VI})$ and lower (II $>\mathrm{MMI}>\mathrm{V}$ ) intensities.

$$
\begin{aligned}
& \mathrm{S}=1.30, \mathrm{R}^{2}=0.98 \\
& \mathrm{MMI}=2.79 \log \left(\mathrm{PGA}_{\text {ave }}\right)+0.32 \\
& \mathrm{~S}=1.36, \mathrm{R}^{2}=0.98
\end{aligned}
$$

Where $\mathrm{S}$ is the standard error of the regression line estimate, and $\mathrm{R}^{2}$ is the coefficient of determination. There is a clear tendency of PGA to increase as MMI increases (Fig. 4, 5). However, there is a significant PGA scatter for a given intensity unit so that a given PGA value could be associated with several intensity levels. The PGA scatter for a particular MMI level has also been observed in previous correlations (Trifunac \& Brady, 1975; Murphy \& O’Brien, 1977; and Wald et al., 1999a).

The large PGA scatter for each MMI may be originated from the definition of the two ground 
shaking parameters. PGA simplifies the complexity of ground shaking without considering factors such duration, spectral content, and resonance that may considerably affect the MMI estimate. MMI considers a subjective description of human response to ground shaking and a description of building damage. Therefore, numerous factors may affect the MMI estimate at a particular site such density of population, building practices, type of construction, and social, economic, and cultural environment. Another aspect that contributes to the scatter is that PGA only refers to a maximum value at single point as opposed to MMI that refers to a maximum or average level of damage and earthquakes effects throughout an area.

Although 330 points represent the largest uniformly processed set of PGA and MMI data ever collected for Costa Rica, the number of PGA that can be used for correlating with MMI is still not sufficient to cover intensity levels of VI and above. Also, there is no PGA data available for MMI above VIII. For this reason, two separate PGA vs. MMI correlations were calculated: one for the well documented MMI range from II to V and another for the MMI range from V to VII. The MMI V-toVII curve was assigned to intersect the MMI II-to$\mathrm{V}$ relationship at MMI V. The correlations obtained are given by the equations (Fig. 5C):

$$
\begin{aligned}
& \mathrm{MMI}=2.30 \log \left(\mathrm{PGA}_{\max }\right)+0.92 \\
& \mathrm{II}>\mathrm{MMI}>\mathrm{V} \\
& \mathrm{MMI}=3.82 \log \left(\mathrm{PGA}_{\max }\right)-1.78 \\
& \mathrm{~V}>\mathrm{MMI}>\mathrm{VII}
\end{aligned}
$$

In order to compare to previous correlations, a regression line using the PGAave arithmetic mean for a given intensity unit was also calculated. The correlations obtained are given by the equations (Fig. 5D):

$$
\begin{aligned}
& \mathrm{MMI}=2.33 \log \left(\mathrm{PGA}_{\text {ave }}\right)+0.76 \\
& \mathrm{II}>\mathrm{MMI}>\mathrm{V} \\
& \mathrm{MMI}=4.60 \log \left(\mathrm{PGA}_{\text {ave }}\right)-3.38 \\
& \mathrm{~V}>\mathrm{MMI}>\mathrm{VII} \quad \text { (6) }
\end{aligned}
$$

Predicted PGA intervals for each MMI value are proposed based on equations 3 to 6 (Table 3). Since MMI are represented only by integer values, PGA interval boundaries were calculated following a rounding convention that, for example, values between 5.50 and 6.49 round to intensity VI. The PGA intervals for a given intensity unit are likely to change if additional data are included particularly if higher intensities (MMI > VI) are considered.

Given that the majority of the data points are represented by shallow earthquakes $(<40 \mathrm{~km})$, recorded at soft soils with hypocentral distance of less than $150 \mathrm{~km}$, regression lines were also calculated using only data points with these characteristics (184 points). The correlations obtained are given by the equations:

$$
\begin{aligned}
& \mathrm{MMI}=2.50 \log \left(\mathrm{PGA}_{\max }\right)+0.76 \\
& \mathrm{~S}=1.42, \mathrm{R}^{2}=0.97 \\
& \mathrm{MMI}=2.60 \log \left(\mathrm{PGA}_{\text {ave }}\right)+0.53 \\
& \mathrm{~S}=1.45, \mathrm{R}^{2}=0.97
\end{aligned}
$$

\section{Comparison with other correlations}

The PGA ${ }_{\max }$ vs. MMI correlation obtained in this study is very similar to the correlation obtained by Wald et al. (1999a) for California using

Table 3

Proposed ranges of PGA for each MMI in Costa Rica

\begin{tabular}{ccccc}
\hline Intensity $(\mathrm{MM})$ & PGAmax range $\left(\mathrm{cm} / \mathrm{s}^{2}\right)$ & PGAmax range $(\% \mathrm{~g})$ & PGAmax range $\left(\mathrm{cm} / \mathrm{s}^{2}\right)$ & PGAmax range $(\% \mathrm{~g})$ \\
\hline II & $<4.9$ & $<0.5$ & $<5.6$ & $<0.6$ \\
III & $4.9-13.3$ & $0.5-1.4$ & $5.6-15.0$ & $0.6-1.5$ \\
IV & $13.3-36.0$ & $1.4-3.7$ & $15.0-40.3$ & $1.5-4.1$ \\
V & $36.0-80.3$ & $3.7-8.2$ & $40.3-84.7$ & $4.1-8.6$ \\
VI & $80.3-146.7$ & $8.2-15.0$ & $84.7-139.6$ & $8.6-14.2$ \\
VII & $146.7-268.0$ & $15.0-27.3$ & $139.6-230.2$ & $14.2-23.5$ \\
\hline
\end{tabular}




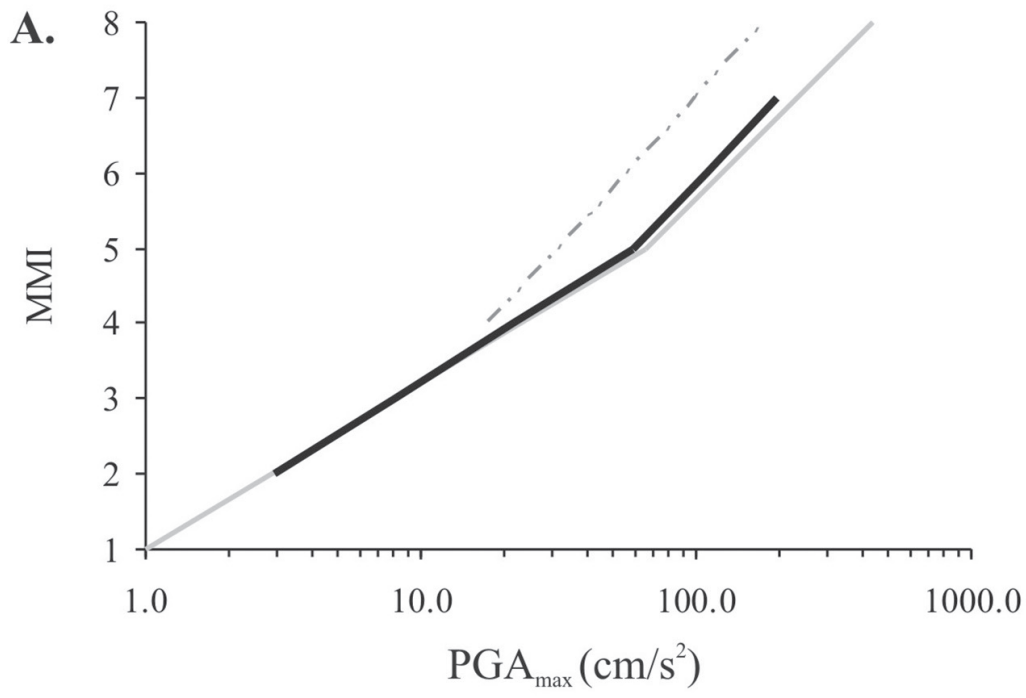

-..- Western USA, Japan, and Southern Europe (Murphy and O'Brien, 1977) California (Wald et al., 1999a)

Costa Rica (this study)

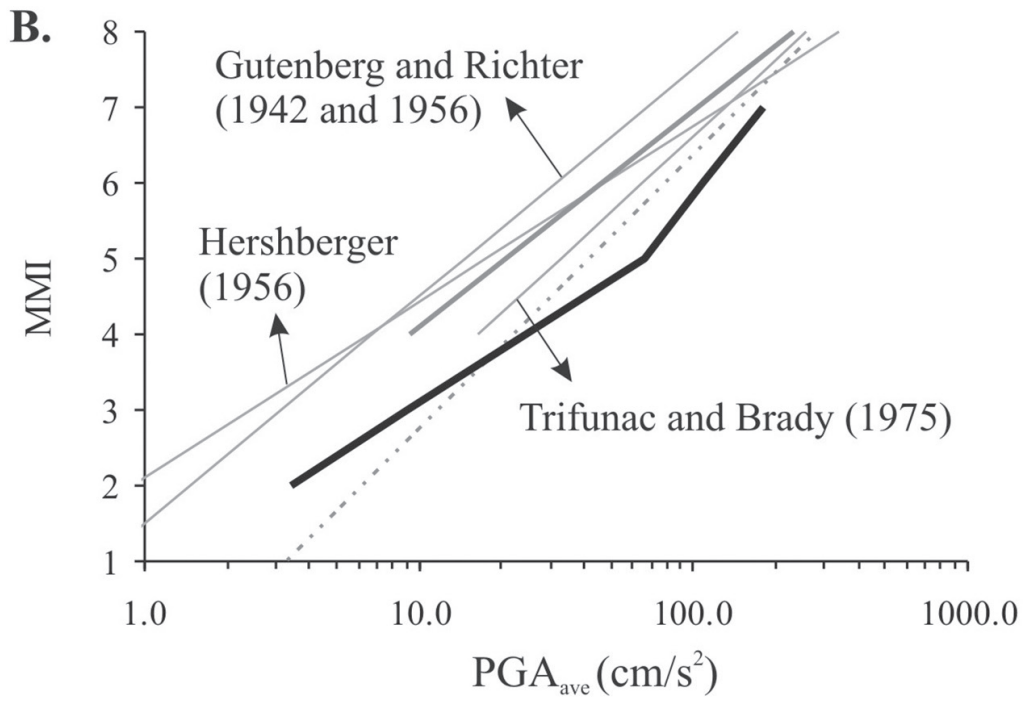

Western USA (see references in the graph)

Unspecified (Sauter, 1978)

Western USA, Japan, and Southern Europe (Murphy and O'Brien, 1977)

Costa Rica (this Study)

Fig. 6: A) Comparison of PGAmax vs. MMI correlations. Regression lines from this study and Wald et al. (1999a) were calculated on the geometric mean of the PGAmax for each intensity unit. Murphy and O'Brien (1977) regression line was performed on the arithmetic mean of the PGAmax for each intensity unit. B) Comparison of PGAave vs. MMI correlations for which regression lines were calculated on the PGAave arithmetic mean for each intensity unit. 
eight significant earthquakes that occurred between 1971 and 1992 (Fig. 6A). The PGAave vs. MMI correlation obtained in this study differs considerably with respect to previous correlations (Fig. 6B). In this case the relationship for Costa Rica indicates lower intensity levels associated with the same PGA for all correlations except for MMI < IV in the correlation presented by Sauter $\&$ Shah (1978). There are a number of factors that may influence the differences between correlations, such as the number of observations used and the distribution of MMI values within each data set. Sufficient data are not yet available to determine whether the differences between correlations are due variations in the tectonic setting in which the earthquakes take place or to a measurement bias associated with factors that alter the assignment of intensities in each particular region, especially those that affect the shaking-damage relationship (i.e. building practices).

\section{Limitations of the PGA vs. MMI correlation}

A fundamental limitation of the correlation is the wide PGA scatter for each MMI level. This large PGA scatter has resulted in critics on this subject (Caputo, 1983). The nature of the two ground shaking parameters that are correlated may explain the wide scatter. PGA only refers to a maximum value at single point and MMI refers to a maximum or average level of earthquakes effects throughout an area.

The PGA vs. MMI correlation calculated here is biased on the observation period from 1983 to 2004 . At present there is little data to correlate intensity levels of VI and VII to PGA and there is no data available for $\mathrm{MMI} \geq \mathrm{VIII}$ to make correlations. Additional data may change the correlation as observed in California by Wald et al. (1999a) who, using earthquakes from 1971 to 1992 , found a different correlation as the relationship presented by Trifunac \& Bradly (1975), who used earthquakes prior to 1971. Also, the data set is biased to local earthquakes (depth $<40 \mathrm{~km}$, hypocentral distance $<$ $150 \mathrm{~km}$ ) recorded at stations located at soft soil sites (Fig. 3). Currently, there is not sufficient data to determine if the PGA vs. MMI correlation is different for particular ranges of focal depth, hypocentral distance or soil type. Hence, the relationships found in this study may be improved with the addition of more observations as they become available.

Recent analyses favor the correlation of MMI with Peak Ground Velocity (PGV) instead of PGA. Wald et al. (1999a) showed that for higher intensities (MMI > VII) PGV provides a more appropriate estimate of intensity. Boatwright et al. (2001) and Wu et al. (2003) found that earthquake damage statistics give a closer correlation with PGV than with PGA. The response spectra of 5\%-damped pseudoacceleration is also proposed as an instrumental parameter to correlate with MMI (Atkinson \& Boore, 1995; Atkinson 2001).

For MMI $\leq$ VI Wald et al. (1999a) support the use of PGA to estimate MMI, since lower intensities are mostly based on human response to ground shaking and people are more sensitive to ground accelerations than velocity. This supports the use of the correlations presented in this study that are valid in the MMI range II to VII. PGV vs. MMI correlations will be addressed in future studies for the Costa Rican region.

Future work should also attempt to describe the MMI vs. PGA correlation using data recorded at stations located in soft soils (i.e, describe the ranges for each intensity degree and the correlation for higher and lower MMI values). Available ground motion data for Central America is also considered as a potential database for future studies in this subject.

\section{CONCLUSIONS}

The first relationship between MMI and the horizontal component of PGA was developed for Costa Rica using regression analysis of $330 \mathrm{MMI}-$ PGA observations from 108 earthquakes $(2.8<\mathrm{Mw}$ $<7.7)$ that took place between 1983 and 2004. The data set is mostly composed of local earthquakes (depth $<40 \mathrm{~km}$, hypocentral distance $<150 \mathrm{~km}$ ) recorded at stations located at soft soil sites.

There is a clear tendency of PGA to increase as MMI increases, however, there is a significant 
PGA scatter for a given intensity unit. Best-fit lines showing this tendency were calculated between MMI and both the largest of the two horizontal components $\left(\mathrm{PGA}_{\max }\right)$ and the average of the two horizontal components $\left(\mathrm{PGA}_{\text {ave }}\right)$. The relationships obtained are: $\mathrm{MMI}=2.30 \log \left(\mathrm{PGA}_{\max }\right)$ +0.92 and $\mathrm{MMI}=2.33 \log \left(\mathrm{PGA}_{\text {ave }}\right)+0.76$ for II $>$ MMI $>$ V and $\mathrm{MMI}=3.82 \log \left(\mathrm{PGA}_{\max }\right)-1.78$ and $\mathrm{MMI}=4.60 \log \left(\mathrm{PGA}_{\text {ave }}\right)-3.38$ for $\mathrm{V}>\mathrm{MMI}$ $>$ VII. Predicted PGA intervals for each MMI value were proposed based on these equations (Table 3). The results are subject to revision to accommodate additional observations as more data become available.

There is a fairly remarkable agreement between the PGAmax vs. MMI correlation obtained in this study and the correlation calculated by Wald et al. (1999a) for California. The PGA ${ }_{\text {ave }}$ vs. MMI correlation indicates lower intensity levels associated with the same PGA with respect to previous correlations. Sufficient data are not yet available to explain these differences.

The empirical relationships found in this study are expected to motivate the development in Costa Rica of shaking intensity maps like those created in the United States within a few minutes of the occurrence of felt earthquakes.

\section{ACKNOWLEDGEMENTS}

Partial funding for this study was provided by a ChevronTexaco Geology Fellowship and the John and Nancy Sumner Fellowship Awards from the department of Geosciences of the University of Arizona. Thanks to the LIS personnel, particularly to Víctor Schmidt for his comments and to Carlos Segura, who was in charge of the network data acquisition. Reviews by Susan Beck, David Wald, George Zandt, Clement Chase, Waldo Taylor and María Laporte improved this manuscript. Also thanks to Pablo Ruiz and Marco Barahona for their enthusiastic support during the MMI acquisition right after the occurrence of felt earthquakes.

\section{REFERENCES}

AMBRASEYS, N.N. \& ADAMS, R.D., 2001: The seismicity of Central America: a descriptive catalogue 1898-1995. - 309 págs. Imperial College Press, London.

ATKINSON. G.M., 2001: Linking historical intensity observations with ground-motion relations for eastern North America. Seismol. Res. Let. 72 (5): 560-574.

ATKINSON, G.M.\& BOORE,D.M., 1995: Groundmotion relations for eastern North America. Bull. Seismol. Soc. Amer. 85: 17-30.

ATKINSON, G.M. \& SONLEY, E., 2000: Empirical relationships between Modified Mercalli intensity and response spectra. Bull. Seismol. Soc. Amer. 90: 537-544.

BOATWRIGHT, J., THYWISSEN, K. \& SEEKINS, L., 2001: Correlation of ground motion and intensity for the 17 January 1994 Northridge, California earthquake. Bull. Seismol. Soc. Amer. 91: 739-752.

CANCANI, A., 1904: Sur l'emploi d'une double échelle seismique des intensités empirique et absolute. - Gerlands Beitrigae zur Geophysik, 2: 281-283.

CAPUTO, M., 1983: Are there one-to-one relationships between magnitude, moment, intensity and ground acceleration? - Geophys. J. Royal Astronomical Soc. 72: 83-92.

CHIARUTTINI, C. \& SIRO, L., 1981: The correlation of peak ground horizontal acceleration with magnitude, distance, and seismic intensity for Friuli and Ancona, Italy, and the Alpide belt. - Bull. Seismol. Soc. Amer. 71: 1993-2009. 


\section{COLEGIO FEDERADO DE INGENIEROS Y} ARQUITECTOS, 2003: Código Sísmico de Costa Rica 2002 [3 $3^{\text {a }}$ Ed.]. - 288 págs. Ed. Tecnológica de Costa Rica, Cartago.

GONZÁLEZ,C., 1910: Temblores, terremotos, inundaciones y erupciones volcánicas en Costa Rica 1608-1910 [1 $1^{\text {a }}$ reimpresión]. - 239 págs. Ed. Tecnólogica de Costa Rica, Cartago.

GUPTA, I., 1980: A note on the correlation of Modified Mercalli intensity with peaks of far-field ground motion. - Bull. Seismol. Soc. Amer. 70: 925-932.

GUTENBERG, B. \& RICHTER C.F., 1942: Earthquake magnitude, intensity, energy, and acceleration. - Bull. Seismol. Soc. Amer. 32: 163-191.

GUTENBERG, B. \& RICHTER, C.F., 1956: Earthquake magnitude, intensity, energy, and acceleration (second paper). - Bull. Seismol. Soc. Amer., 46: 105-145.

HERSHBERGER, J., 1956: A comparison of earthquake accelerations with intensity ratings. - Bull. Seismol. Soc. Amer. 46: 317-320.

KAKA,S.\& ATKINSON, G., 2004: Relationships between instrumental ground-motion parameters and Modified Mercalli intensity in eastern North America. - Bull. Seismol. Soc. Amer. 94: 1728-1736.

LINKIMER, L (in press): Application of the kriging method to draw isoseismal maps of the significant 2002-20033 Costa Rican earthquakes. - Rev. Geol. Amér. Central.

MCCANN, M., SAUTER, F. \& SHAH, H.C, 1980: A technical note on the PGA-intensity relations with applications to damage estimation. - Bull. Seismol. Soc. Amer. 70: 631-637.
MURPHY J.R. \& O'BRIEN, L.J., 1977: The correlation of peak ground acceleration amplitude with seismic intensity and other physical parameters. - Bull. Seismol. Soc. Amer. 67: 877-915.

NEUMANN, F., 1954: Earthquake intensity and related ground motion. - 77 págs. University of Washington Press, Seattle.

PERALDO, G. \& MONTERO, W., 1994: Los temblores del período colonial de Costa Rica. - 162 págs. Ed. Tecnológica de Costa Rica, Cartago.

RICHTER, C.F., 1958: Elementary Seismology. - 168 págs. Freeman, San Francisco.

SAUTER,F. \& SHAH,H.C., 1978: Estudio de seguro contra terremoto. - 250 págs. Franz Sauter y Asociados Ltda. San José, Costa Rica.

SCHENK, V., MANTLÍK, F., ZHIZHIN, M.N. \& TUMARKIN, A.G., 1990: Relation between macroseismic intensity and instrumental parameters of strong motion -a statistical approach. - Natural Hazards, 3: 111-124.

TRIFUNAC, M.D. \& BRADY, A.G., 1975: On the correlation of seismic intensity scale with the peaks of recorded strong ground motion. - Bull. Seismol. Soc. Amer. 65: 139-162.

WALD, D.J., QUINTORIANO, V., HEATON, T.H. \& KANAMORI., H., 1999a: Relationships between peak ground acceleration, peak ground velocity, and Modified Mercalli intensity in California. - Earthquake Spectra, 15: 557-564.

WALD, D.J., QUINTORIANO, V., HEATON, T.H., KANAMORI., H., SCRIVNER, C.W., \& WORDEN, C.B., 1999b: TriNet "ShakeMaps": Rapid generation of peak 
ground motion and intensity maps for earthquakes in southern California. Earthquake Spectra, 15: 537-555.

WOOD, H.O. \& NEWMAN, F., 1931: Modified Mercalli intensity of 1931. - Bull. Seismol. Soc. Amer. 21: 277-283.
WU, Y., TENG, T., SHIN, T. \& HSIAO, N., 2003: Relationship between peak ground acceleration, peak ground velocity, and intensity in Taiwan. - Bull. Seismol. Soc. Amer. 93: 386-396. 